\title{
Evaluation of the Growth and the Yield of Eggplant Crop Under Different Irrigation Depths and Magnetic Treatment of Water
}

\author{
Álvaro Henrique Cândido de Souza ${ }^{1}$, Roberto Rezende ${ }^{1}$, Cássio de Castro Seron ${ }^{1}$, Marcelo Zolin Lorenzoni ${ }^{1}$, \\ Jean Marcelo Rodrigues do Nascimeto ${ }^{1}$, Cláudia Salim Lozano ${ }^{1}$, Daniel Nalin ${ }^{2}$, Daniele de Souza Terassi ${ }^{1}$, \\ Antônio Carlos Andrade Gonçalves ${ }^{1}$, Reni Saath ${ }^{1} \&$ Paulo Sérgio Lourenço de Freitas ${ }^{1}$ \\ ${ }^{1}$ Post-graduate in Agronomy, State University of Maringá, Maringá, Paraná, Brazil \\ ${ }^{2}$ Graduate in Agronomy, State University of Maringá, Maringá, Paraná, Brazil \\ Correspondence: Álvaro Henrique Cândido de Souza, Post-graduate in Agronomy, State University of Maringá, \\ Avenue Colombo 5790, Maringá, Paraná, Brazil. Tel: 55-44-3011-8940. E-mail: alvarohcs@hotmail.com
}

Received: July 8, 2019

Accepted: August 15, $2019 \quad$ Online Published: October 15, 2019

doi:10.5539/jas.v11n17p35

URL: https://doi.org/10.5539/jas.v11n17p35

The research is financed by the Coordenação de Aperfeiçoamento de Pessoal de Nivel Superior - Brazil (CAPES).

\begin{abstract}
The use of magnetizers for the treatment of irrigation water can be used in agriculture as an alternative to increase the growth and yield of several crops. The objective of this study was to evaluate the effect of different irrigation depths and magnetic treatment of water on eggplant crop cultivated in protected environment. The study was carried out in two experiments, in the first one, the design was completely randomized with four replications and two factors: water depths (50, 75 and 100\% ETc) for two water qualities (water treated by magnetizers and water without treatment). In the second one, the design was completely randomized with five replicates and two factors: water depths ( 75 and 100\% ETc) for two irrigation water treatment (water treated by magnetizers and water without treatment). In the second experiment was ignored the treatment of 50\% of ETc in order to increase the number of repetitions to check if there are differences between water treated to water without treatment. There were no significant differences in eggplant yield and growth as function of the magnetic treatment of water. The water depth that provided the highest yield, number of fruits per plant and stem dry matter in the two experiments was $100 \%$ ETc regardless of water quality.
\end{abstract}

Keywords: irrigation management, magnetizers, Solanum Melongena L., yield

\section{Introduction}

Due to several reasons, water sources are facing challenges and studies are required for sustainability of agricultural crops (Surendran, Sandeep, \& Joseph, 2016).

Eggplant (Solanum Melongena L.) belongs to the Solanaceae family as well as tomato and bell pepper having similar requirements (Díaz-Pérez \& Eaton, 2015). Studies with eggplant plants indicated that this crop can be grown under water deficit (Kirnak, Tas, Kaya, \& Higgs, 2002; Aujla, Thind, \& Buttar, 2007; Gaveh, Timpo, Agodzo, \& Shin, 2011; Karam et al., 2011).

Surendran, Sandeep, and Joseph (2016) applied magnetic treatment of water in eggplant cultivation and obtained increasing on plant height, number of leaves, leaf area and individual fruit weight, and especially increase in yield of 25.8 and $17.0 \%$ under normal conditions and water saline, respectively.

In a study with different replacement levels and different magnetic flux densities (control, 50, 100 and $200 \mathrm{mT}$ ) in irrigation water for corn crop were observed that magnetization was viable to increase grain yield, regardless of the magnetic flux density that was applied (Fattah \& Aoda, 2008).

Mahmood and Usman (2014) used as source of irrigation water tap water, saline water, water from a canal and also from a sewage system and found that the magnetization of the various water sources increased mass and acceleration of growth. 
Mohammadian et al. (2015) found that magnetically treated water increased sweet pepper yield at different salinity levels, $12 \%, 19 \%$ and $33 \%$ respectively to $0.3,2.3$ and $4.2 \mathrm{ds} \mathrm{m}^{-1}$.

Hozayn et al. (2016) observed that magnetically treated water provided an increase in chlorophyll A of $8.86 \%$, chlorophyll B of $22.22 \%$ and carotenoids of $19.71 \%$ for canola crop. Rawabdeh et al. (2014) found an increase in chlorophyll, carbohydrate, protein and $\mathrm{N}, \mathrm{P}$ and $\mathrm{K}$ absorption in pepper plants irrigated with magnetically treated water.

Fattah and Aoda (2008) defined the magnetic treatment of water as water subjected to the treatment of a magnetic field. The treatment of water with magnetization is a technique known to allow increased water use-efficiency due changes in physical and chemical characteristics of water and soil (Noran, Shani, \& Lin, 1996).

Based on the above, this study aimed to evaluate the response of yield and growth eggplant crop, cv. Nápoli, in function of different irrigation depths and magnetic treatment of water, cultivated in a protected environment.

\section{Methods}

\subsection{Experiment Characterization: Climate, Soil and Fertilization}

The study was conducted at the Irrigation Technical Center (CTI) of the State University of Maringá (UEM), in the municipality of Maringá, Paraná, Brazil (232 $\left.25^{\prime} 57^{\prime \prime} \mathrm{S} ; 51^{\circ} 57^{\prime} 08^{\prime \prime} \mathrm{W} ; 542 \mathrm{~m}\right)$. Two experiments were carried, the first, $18 / 10 / 2017$ to $9 / 04 / 2018$ and the second $16 / 05 / 2018$ to $12 / 12 / 2018$.

The local climate is characterized as humid mesothermal (Cfa), according to the Köppen classification presenting hot summer, without dry season and oceanic climate (Alvares et al., 2013). The weather data were obtained from a meteorological station installed inside the greenhouse. The first and second experiments presented average value for temperature of $25.81^{\circ} \mathrm{C}$ and $22.09{ }^{\circ} \mathrm{C}$ respectively (Figure 1). The most favorable temperature range for eggplant cultivation is 20 to $30^{\circ} \mathrm{C}$ during the day and 15 to $20{ }^{\circ} \mathrm{C}$ at night (Filgueira, 2003).

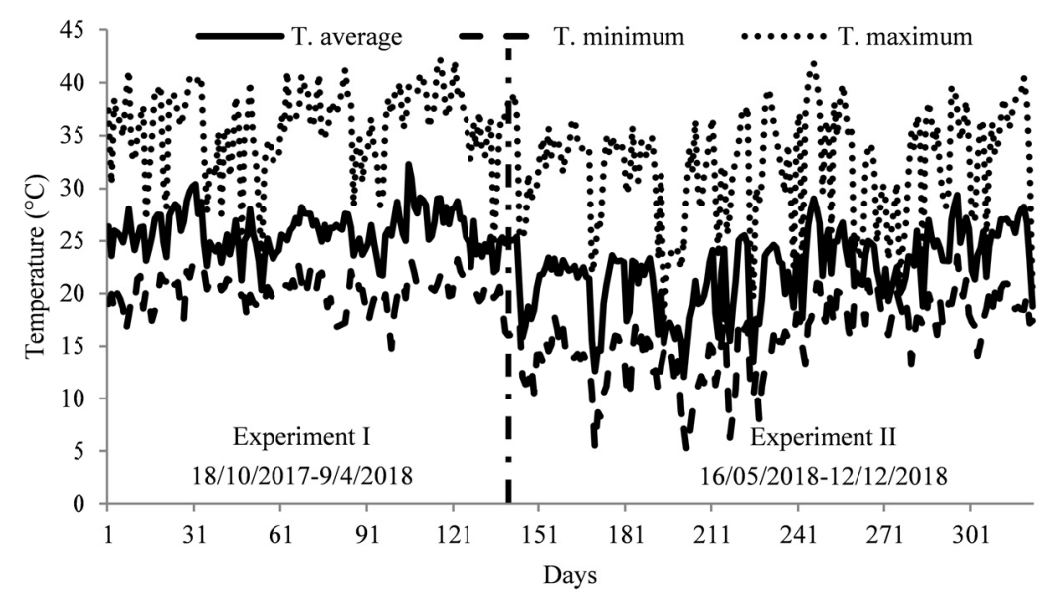

Figure 1. Values for minimum, maximum, average temperature recorded inside the protected environmental

A drip irrigation system was installed with self-compensating drippers $\left(4 \mathrm{~L} \mathrm{~h}^{-1}\right)$ spaced $0.25 \mathrm{~m}$ and operating at pressure of 1 bar $\left(10 \mathrm{mH}_{2} \mathrm{O}\right)$. The irrigation system was evaluated by Christiansen coefficient (CUC), which was 91.6\%, being classified as excellent (Keller \& Bliesner, 1990).

The soil of experimental area is classified as Distroferric Red Nitossol (NVdf) (Embrapa, 2018) with clayey texture (200, 120, $680 \mathrm{~g} \mathrm{~kg}^{-1}$ sandy, silt and clay). Soil chemical analysis was conducted and presented: In mg $\mathrm{dm}^{-3}: 2.82 \mathrm{P} ; 7.72 \mathrm{P}-\mathrm{Rem} ; 9.35 \mathrm{Na}^{+} ; 2.52 \mathrm{~S} ; 12.26 \mathrm{Cu} ; 3.15 \mathrm{Zn} ; 153.10 \mathrm{Fe} ; 39.78 \mathrm{Mn} ; 9.35 \mathrm{Na}^{+}$and $0.05 \mathrm{~B}$. In $\mathrm{cmol}_{\mathrm{c}} \mathrm{dm}^{-3}: 0.08 \mathrm{~K}^{+} ; 1.11 \mathrm{Ca}^{2+} ; 1.05 \mathrm{Mg}^{2+} ; 0.45 \mathrm{Al}^{3+}$ and $4.33 \mathrm{H}^{+}$. The value for organic matter was $9.86 \mathrm{~g} \mathrm{dm}^{-3}$, $5.72 \mathrm{~g} \mathrm{dm}^{-3}$ of organic carbon, $4.5 \mathrm{pH}$ in $\mathrm{CaCl}_{2}$ and $5.0 \mathrm{pH}$ in $\mathrm{H}_{2} \mathrm{O}$.

According to chemical analysis it was verified the need for basal fertilization per hectare of: $490 \mathrm{~kg}$ triple superphosphate $\left(41 \% \mathrm{P}_{2} \mathrm{O}_{5}\right.$ and $\left.14 \% \mathrm{Ca}^{2+}\right), 20 \mathrm{t}$ organic fertilizer, $3.21 \mathrm{t}$ calcitic limestone (PRNT $=83.1 \%, 45 \%$ $\mathrm{CaO}$ and $4.9 \% \mathrm{MgO}), 150 \mathrm{~kg}$ ammonium sulfate $(20 \% \mathrm{~N}$ and $24 \% \mathrm{~S}), 8.8 \mathrm{~kg}$ boric acid $(17 \% \mathrm{~B})$ and $180 \mathrm{~kg}$ 
potassium chloride $\left(60 \% \mathrm{~K}_{2} \mathrm{O}\right)$. These applications were performed 30 days before the transplantation of the Experiment I, in according to Trani (2014), and Ribeiro, Guimarães, and Alvarez (1999).

After transplanting in Experiment I and II, both had fertigation with $160 \mathrm{~kg} \mathrm{de} \mathrm{N} \mathrm{ha}^{-1}$ (urea) (Souza et al., 2017) and $120 \mathrm{~kg} \mathrm{~K}_{2} \mathrm{O} \mathrm{ha}^{-1}$ (potassium chloride) (Trani, 2014) following absorption march of eggplant crop (Trani et al., 2011).

\subsection{Experiment I: Design and Plot}

The first experiment was completely randomized with factorial arrangement $(3 \times 2)$, with three replications, the first factor was three water depths $(50,75$ and $100 \%$ ETc) and the second factor was irrigation water treatment (water treated by magnetizers and water without treatment).

The plants were spaced $0.75 \mathrm{~m}$ apart, and laterals rows were spaced $1.0 \mathrm{~m}$ apart. Each experimental unit had four plants. The plants beds were constructed with dimensions of $3.0 \mathrm{~m}$ in length, $0.5 \mathrm{~m}$ in width and $0.15 \mathrm{~m}$ in height It was considered as a useful area only the two central plants in the beds.

The eggplant seedlings cv. Napoli were produced in polyethylene trays filled with commercial substrate for experiment I and II. In the first experiment the transplanting was performed on 17/11/2017 and the treatments started 19 days after transplanting (DAT) and the last harvest was performed on 9/4/2018.

\subsection{Experiment II: Design and Plot}

The second experiment was completely randomized with factorial arrangement $(2 \times 2)$, with five replications, the first factor was two water depths ( 75 and $100 \%$ ETc) and the second factor was irrigation water treatment (water treated by magnetizers and water without treatment).

The plants were spaced $1.5 \mathrm{~m}$ apart, and laterals rows were spaced $1.0 \mathrm{~m}$ apart. Each experimental unit had one plant. The plants beds were constructed with dimensions of $1.5 \mathrm{~m}$ in length, $0.5 \mathrm{~m}$ in width and $0.15 \mathrm{~m}$ in height. The distances between the plants were extended because in the first experiment there was difficulty moving between plants due to large growth.

The seedlings were transplanted on 15/06/2018 with start of treatments at 20 DAT and had the last harvest on $12 / 12 / 2018$.

\subsection{Irrigation Management}

The crop water replacement was started at 7:00 in the morning every Monday, Wednesday and Friday. The depths were based on the crop evapotranspiration (ETc) which is the product of reference crop evapotranspiration $\left(\mathrm{ET}_{0}\right)$ and crop coefficient $(\mathrm{Kc}) . \mathrm{ET}_{0}$ was estimated by Penman-Monteith equation (Allen, Pereira, Raes, \& Smith, 1998) (Equation 1). Kc values considered were 0.4 (initial), 0.75 (crop development), 1.10 (mid-season) and 0.75 (late season) (Marouelli, Silva, \& Silva, 2001).

$$
\mathrm{ET}_{0}=\frac{0.408 \Delta(\mathrm{Rn}-\mathrm{G})+\gamma \frac{900}{\mathrm{~T}+273} \mathrm{U}\left(\mathrm{e}_{\mathrm{s}}-\mathrm{e}_{\mathrm{a}}\right)}{\Delta+\gamma(1+0.34 \mathrm{U})}
$$

Where, $\mathrm{ET}_{0}$ : reference evapotranspiration, $\mathrm{mm} \mathrm{day}^{-1} ; \Delta$ : slope vapour pressure curve, $\mathrm{kPa}^{\circ} \mathrm{C}^{-1} ; \mathrm{Rn}$ : net radiation at the crop surface, $\mathrm{MJ} \mathrm{m}^{-2} \mathrm{day}^{-1}$; $\mathrm{G}$ : soil heat flux density, $\mathrm{MJ} \mathrm{m}^{-2}$ day $^{-1} ; \gamma$ : psychrometric constant, $\mathrm{kPa}^{\circ} \mathrm{C}^{-1} ; \mathrm{T}$ : mean daily air temperature at $2 \mathrm{~m}$ height, ${ }^{\circ} \mathrm{C}$; U: Wind speed at $2 \mathrm{~m}$ height, $\mathrm{m} \mathrm{s}^{-1} ; \mathrm{e}_{\mathrm{s}}$ : saturation vapour pressure, $\mathrm{kPa}$; $\mathrm{e}_{\mathrm{a}}$ : actual vapour pressure, $\mathrm{kPa}$; es-ea: saturation vapour pressure déficit, $\mathrm{kPa}$.

The wind speed values considered for the $\mathrm{ET}_{0}$ calculation were $5 \%$ of the external wind speed (Prados, 1986).

\subsection{Magnetic Water Treatment}

The water treatment was carried out for a period of 24 hours in a water box (500 liters) using a magnetizer composed of alternating magnets sealed by a stainless steel structure. The magnetic flux density of field (B) was measured by the apparatus 425 Gaussmeter (LakeShore).

The measurement of $\mathrm{B}$ was performed in the radial direction and the tip of the hall effect model of planar tip HMNT-4E04-VR Lakeshore was used. Equipment calibration was performed with the model 4060 Lakeshore Gauss zero chamber. The highest verified value corresponded to $100 \mathrm{mT}$ (militesla) which is equivalent to 1000 Gauss. The magnetizing device consists of a cylindrical piece of $16.8 \mathrm{~cm}$ in height and $10 \mathrm{~cm}$ in diameter, being shielded in stainless steel with magnets inside.

\subsection{Measurement of Plants}

The fruits which were considered for weighing showed a shiny dark purple color, longer than $14 \mathrm{~cm}$ and $5 \mathrm{~cm}$ of transverse diameter (Luengo et al., 1999). The sum of weight of all fruits considered per plant resulted in the 
productivity per plant and the counting them resulted in the number of fruits per plant. The ratio of productivity per plant by number of fruits per plant resulted in average fruit weight.

The water use-efficiency (WUE) $\left(\mathrm{g} \mathrm{g}^{-1}\right)$ was calculated by ratio productivity per plant $\left(\mathrm{Y}_{\mathrm{i}}\right)\left(\mathrm{g} \mathrm{plant}^{-1}\right)$ by amount of water applied per plant $\left(\mathrm{I}_{\mathrm{i}}\right)\left(\mathrm{g} \mathrm{plant}^{-1}\right)$ according to Equation 2 (Levidow et al., 2014).

$$
\mathrm{WUE}_{\mathrm{i}}=\frac{\mathrm{Y}_{\mathrm{i}}}{\mathrm{I}_{\mathrm{i}}}
$$

Where, WUE $\mathrm{E}_{\mathrm{i}}$ : water use-efficiency $\left(\mathrm{g} \mathrm{g}^{-1}\right)$; $\mathrm{Y}_{\mathrm{i}}$ : productivity per plant $\left(\mathrm{g} \mathrm{plant}^{-1}\right) ; \mathrm{I}_{\mathrm{i}}$ : amount of water applied per plant $\left(\mathrm{g}\right.$ plant $\left.{ }^{-1}\right)$.

The determination of the relative water content (RWC) (Equation 3) for the Experiment I on 10/04/2018 following the methodology proposed by Jamaludin, Aziz, Ahmad, and Jaafar (2015) in which samples of leaf discs were taken and weighed immediately by a digital scale with a precision of $0.01 \mathrm{~g}$ for determination of the fresh weight (FW). After weighing, the samples were floated in distilled water and kept in the dark for $24 \mathrm{~h}$ to regain full turgor. Then, the leaf discs were removed and excess water was removed using a paper tissue to determine the turgid weight (TW). The samples were dried in a forced circulation oven at $60^{\circ} \mathrm{C}$ for $48 \mathrm{~h}$ in order to reach the constant mass and determination of dry weight (DW).

$$
\mathrm{RWC}=\frac{\mathrm{FW}-\mathrm{DW}}{\mathrm{TW}-\mathrm{DW}}
$$

For determination of photosynthetic pigments was used the methodology proposed by Arnon (1949) adapted by Lichtenthaler (1987). The methodology consists in obtaining two leaf discs, conditioning the plant material in 5 $\mathrm{mL}$ of $80 \%$ acetone for seven days in the dark at $25^{\circ} \mathrm{C}$ and then performing spectrophotometer readings at 663 $\mathrm{nm}, 645 \mathrm{~nm}$ and $470 \mathrm{~nm}$, respectively for chlorophyll $\mathrm{A}, \mathrm{B}$ and carotenoids.

Height and diameter measurements were performed at the end of the cycle using a digital measuring tape and caliper respectively. The leaf area was measured by leaf reader LI 3100 immediately after separation of leaves and stems. The roots of the plants were extracted using a root sampler with dimensions of $20 \mathrm{~cm}$ wide, $25 \mathrm{~cm}$ long and $25 \mathrm{~cm}$ deep. During the sampling the sampler was introduced into the soil with the aid of hammer.

The evaluations of stem dry matter (SDM), leaf dry matter (LDM) and root dry matter (RDM) were performed at the end of the experiment. The drying of the plant parts was carried out in a forced circulation oven at $60{ }^{\circ} \mathrm{C}$ until reaching a constant mass. After drying, the plant parts were weighed on a precision digital scale $(0.001 \mathrm{~g})$.

The time for the occurrence of the first flower was measured by the interval between the day of transplanting (DAT) and the complete development of the first flower of the eggplant plant.

\subsection{Statistical Analysis}

The data were subjected to analysis of variance (ANOVA) by F test and Tukey test at 0.05 probability level using Software Sisvar (Ferreira, 2014) to compare the effects of factors and its interaction for all studied variables.

\section{Results and Discussion}

According to the analysis of variance there were no significant differences for the variables evaluated as a function of irrigation water treatment in the Experiment I (Table 1). These results differ from Surendran, Sandeep, and Joseph (2016) who observed a $25.8 \%$ increase in eggplant productivity under irrigation with magnetically treated water. However, these same authors did not find significant differences in bean plants that received magnetically treated water, but for water with a large amount of salts the magnetic treatment technique increased the yield of bean and eggplant. 
Table 1. F values from analysis of variance for the variables of growth, productivity and photosynthetic pigment of eggplant as function of different water depths and magnetic treatment of water (Experiment I)

\begin{tabular}{|c|c|c|c|c|c|}
\hline \multirow{2}{*}{ Variables } & \multicolumn{3}{|c|}{ F values } & \multirow{2}{*}{ CV $(\%)$} & \multirow{2}{*}{ Average } \\
\hline & Water treatment (WT) & Water depths (WD) & $\mathrm{WT} \times \mathrm{WD}$ & & \\
\hline Productivity & $0.083^{\mathrm{ns}}$ & $6.218^{* *}$ & $0.110^{\mathrm{ns}}$ & 28.06 & 1331.95 g plant $^{-1}$ \\
\hline Number of fruits per plant & $1.058^{\mathrm{ns}}$ & $4.279^{*}$ & $0.038^{\mathrm{ns}}$ & 30.18 & 6.91 \\
\hline Average fruit weight & $2.505^{\mathrm{ns}}$ & $0.546^{\mathrm{ns}}$ & $0.497^{\mathrm{ns}}$ & 19.79 & $192.78 \mathrm{~g} \mathrm{fruit}^{-1}$ \\
\hline Stem dry matter & $0.791^{\mathrm{ns}}$ & $11.797^{* *}$ & $1.743^{\mathrm{ns}}$ & 20.05 & 234.38 g plant $^{-1}$ \\
\hline Leaf dry matter & $0.526^{\mathrm{ns}}$ & $0.566^{\mathrm{ns}}$ & $1.198^{\mathrm{ns}}$ & 31.18 & $87.64 \mathrm{~g} \mathrm{plant}^{-1}$ \\
\hline Root dry matter & $0.001^{\text {ns }}$ & $0.131^{\mathrm{ns}}$ & $0.721^{\mathrm{ns}}$ & 28.32 & $111.13 \mathrm{~g} \mathrm{plant}^{-1}$ \\
\hline Leaf area & $0.269^{\text {ns }}$ & $1.299^{\mathrm{ns}}$ & $2.788^{\text {ns }}$ & 21.65 & $13075.55 \mathrm{~cm}^{2}$ plant ${ }^{-1}$ \\
\hline Height & $1.165^{\mathrm{ns}}$ & $5.934^{*}$ & $8.314^{* *}$ & 9.98 & $128.83 \mathrm{~cm}$ \\
\hline Diameter & $1.511^{\mathrm{ns}}$ & $1.070^{\mathrm{ns}}$ & $5.599^{*}$ & 13.07 & $19.11 \mathrm{~mm}$ \\
\hline Chlorophyll A & $0.001^{\text {ns }}$ & $2.766^{\mathrm{ns}}$ & $3.198^{\text {ns }}$ & 7.05 & $0.0097 \mu \mathrm{g} \mathrm{g}^{-1}$ \\
\hline Chlorophyll B & $1.206^{\mathrm{ns}}$ & $6.573^{*}$ & $12.157^{* *}$ & 7.15 & $0.003342 \mu \mathrm{g} \mathrm{g}^{-1}$ \\
\hline Carotenoids & $3.230^{\mathrm{ns}}$ & $2.375^{\mathrm{ns}}$ & $4.340^{*}$ & 12.06 & $0.0042952 \mu \mathrm{g} \mathrm{g}^{-1}$ \\
\hline RWC & $0.070^{\text {ns }}$ & $0.392^{\mathrm{ns}}$ & $2.835^{\mathrm{ns}}$ & 6.13 & $82.49 \%$ \\
\hline
\end{tabular}
according to the F-test.

The application of the different water depths caused significant differences in productivity, number of fruits per plant, stem dry matter, height and chlorophyll B. From the statistical results obtained for productivity and number of fruits per plant, it can be concluded that the depth of $100 \%$ ETc differed significantly only from the $50 \%$ ETc depth (Figure 2).

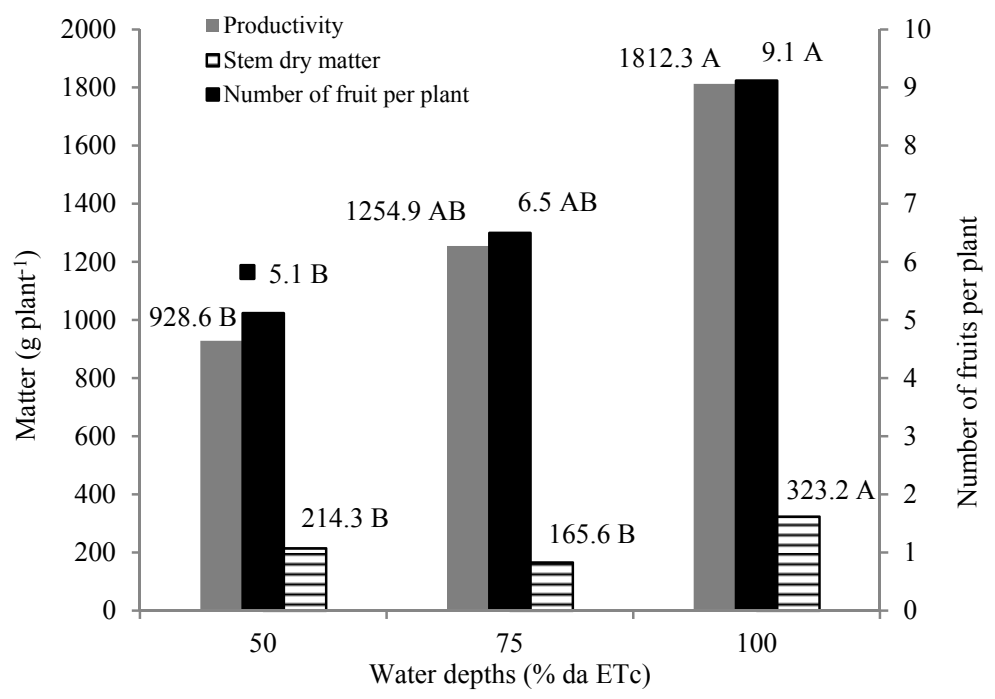

Figure 2. Productivity, number of fruit per plant and stem dry matter in function of water depths applied on eggplants. Averages followed by the same letter do not differ statistically $(p>0.05)$ by the Tukey test

The highest mean observed was $1812.3 \mathrm{~g}$ and 9.1 fruits per plant for the $100 \%$ ETc (Figure 2). Bilibio et al. (2010a) tested in the Nápoli hybrid, 50-150\% of the replacement depth and obtained the highest productivity of 2000 g plant $^{-1}$ with $150 \%$. Karam et al. (2011) observed that the water deficit reduces productivity in comparison with the control treatment, however in the case of water use-efficiency the treatments with water deficit exceed the control treatment.

The productivity values showed a high correlation $(\rho=0.89)$ with number of fruits per plant. This correlation agrees with the work of Díaz-Pérez and Eaton (2015) who verified high values $(\rho=0.96)$ and Aujla, Thind, and Buttar (2007) $(\rho=0.80)$ between the same variables. 
Although water deficit irrigation levels caused significant differences in productivity and number of fruits per plant, there was no difference in the average fruit weight. This behavior was also verified by Chartzoulakis and Drosos (1995).

The stem dry matter did not show significant differences between the 50 and $75 \%$ ETc depths and between the 75 and $100 \%$ ETc depths, but it can be affirmed that there was a difference between the 100 and $50 \%$ ETc.

There were significant differences for two photosynthetic pigments, chlorophyll B and carotenoids. Chlorophyll $B$ showed a significant difference between the irrigation depth of 50 and $100 \%$ ETc, with 0.0036 (A), 0.0034 (AB) and $0.0030 \mu \mathrm{g} \mathrm{g}^{-1}$ (B) respectively for the depths 50,75 and $100 \%$ of ETc.

In the experiment II, there were significant differences in productivity, number of fruits per plant, average fruit weight, stem dry matter, leaf dry matter and diameter under the effect of water depths (Table 2). These variables were higher when they received the $100 \%$ ETc irrigation depth. There were no significant differences for the effect of water treatment and its interactions.

Table 2. $\mathrm{F}$ values from analysis of variance for the variables of growth, productivity, development and water use-efficiency of the eggplant as function of different water depths and magnetic treatment of irrigation water (Experiment II)

\begin{tabular}{|c|c|c|c|c|c|}
\hline \multirow{2}{*}{ Variables } & \multicolumn{3}{|c|}{$F$ values } & \multirow{2}{*}{$\mathrm{CV}(\%)$} & \multirow{2}{*}{ Average } \\
\hline & $\begin{array}{l}\text { Water treatment (WT) } \\
\text { (W) }\end{array}$ & Water depths (WD) & $\mathrm{WT} \times \mathrm{WD}$ & & \\
\hline Productivity & $0.053^{\mathrm{ns}}$ & $8.432^{*}$ & $0.66^{\mathrm{ns}}$ & 24.25 & 4345.13 g plant $^{-1}$ \\
\hline Number of fruit per plant & $0.058^{\mathrm{ns}}$ & $18.485^{* *}$ & $0.114^{\mathrm{ns}}$ & 25.93 & 17.85 \\
\hline Average fruit weight & $0.627^{\mathrm{ns}}$ & $7.898^{*}$ & $0.05^{\mathrm{ns}}$ & 15.02 & $253.44 \mathrm{~g}_{\text {fruit }^{-1}}$ \\
\hline Stem dry matter & $1.744^{\mathrm{ns}}$ & $9.146^{* *}$ & $0.023^{\mathrm{ns}}$ & 34.79 & 304.84 g plant $^{-1}$ \\
\hline Leaf dry matter & $0.864^{\mathrm{ns}}$ & $15.851^{* *}$ & $1.53^{\mathrm{ns}}$ & 22.44 & 108.27 g plant $^{-1}$ \\
\hline Height & $0.323^{\mathrm{ns}}$ & $2.758^{\mathrm{ns}}$ & $0.323^{\mathrm{ns}}$ & 8.32 & $123.00 \mathrm{~cm}$ \\
\hline Diameter & $0.187^{\mathrm{ns}}$ & $13.241^{* *}$ & $3.010^{\mathrm{ns}}$ & 5.90 & $21.06 \mathrm{~mm}$ \\
\hline WUE & $0.012^{\mathrm{ns}}$ & $0.066^{\mathrm{ns}}$ & $0.548^{\mathrm{ns}}$ & 26.14 & $13.63 \mathrm{~g} \mathrm{~g}^{-1}$ \\
\hline First flower & $0.070^{\mathrm{ns}}$ & $2.514^{\mathrm{ns}}$ & $2.514^{\mathrm{ns}}$ & 8.92 & 56.9 DAT \\
\hline
\end{tabular}

There was no difference for WUE as function of water treatment and water depths. Kirnak, Tas, Kaya, and Higgs (2002) verified that the highest water use-efficiency occurred with the replacement of $80 \%$ of the total. Díaz-Pérez and Eaton (2015) found a reduction in water use-efficiency with the increase of irrigation depths.

The average productivity in the experiment II (4345.13 g plant $\left.^{-1}\right)$ was $226.2 \%$ more than the average obtained in the experiment I (1331.95 g plant $\left.{ }^{-1}\right)$, this difference was probably due to the difference in spacing and climate conditions.

Bilibio et al. (2010b) obtained the highest productivity $1720 \mathrm{~g} \mathrm{plant}^{-1}$ when was used as the irrigation criterion the highest water tension in the soil $(-15 \mathrm{KPa})$ which provided higher water replenishment. Diaz-Pérez and Eaton (2015) verified that the $67 \%$ ETc depth induced moderate water stress, causing no damage to growth, productivity and gas exchange, with similar results with irrigated plants under $100 \%$ ETc.

The $75 \%$ ETc depth resulted in a $28 \%$ reduction in the productivity compared to the $100 \%$ ETc (Figure $4 \mathrm{~A}$ ), but there were no differences for the water use-efficiency variable, therefore, the use of the depth of $100 \%$ ETc was more productive. The values of eggplant yield in response to water deficit approximated the values observed by Kirnak, Tas, Kaya, and Higgs (2002) found a reduction in productivity of 12 and 28\%, respectively, for 80 and $70 \%$ of replacement of the water estimated by Pan Evaporation. 

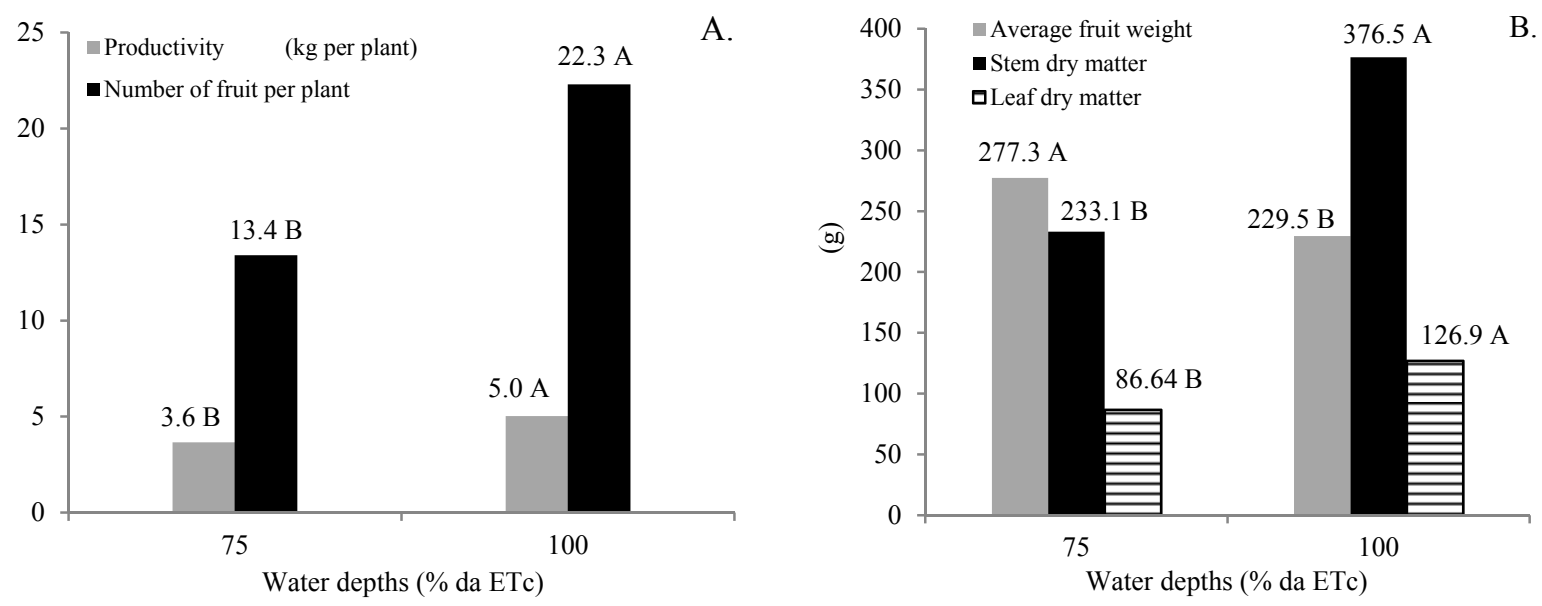

Figure 4. A) Productivity, number of fruit per plant, B) average fruit weight, stem and leaf dry matter in function of water depths applied on eggplants. Averages followed by the same letter do not differ statistically $(p>0.05)$

by the Tukey test

In Figure 4, it was verified that the average fruit weight was higher with the $75 \%$ water depth, this may explain the highest productivity with $100 \%$ ETc was due increasing of number of fruits and not due fruit growth therefore having more number of fruits the average fruit weight decreased.

The highest stem dry matter and leaf dry matter were observed with the application of the 100\% ETc depth, being respectively 376.5 and $126.9 \mathrm{~g}$ (Figure 4B). The stem diameter showed significant differences for the different depths applied, being 20.04 and $22.07 \mathrm{~mm}$ respectively for 75 and $100 \%$ of ETc. Bilibio et al. (2010b) verified that the stem diameter showed a linear decreasing response due to the reduction of soil moisture and the largest diameter value found was $16.81 \mathrm{~mm}$.

About the effect of the treatments on the development of the plants, the date of the first flower was evaluated, however, no significant difference was verified for the formation of the first flower in the plants $($ mean $=56.9$ DAT). Bilibio et al. (2010b) studied the effect of water depths on eggplant crop and verified that the first flower appeared between 10 and 34 DAT.

\section{Conclusion}

Magnetic treatment of irrigation water did not influence the productivity and growth of eggplant plants.

The 100\% water depth of ETc provided higher productivity value and number of fruits per plant compared to water depths expressing water deficit regardless of water quality.

Eggplant plants cultivated with 100\% ETc water depth showed higher stem and leaf dry matter accumulation.

\section{References}

Allen, R. G., Pereira, L. S., Raes, D., \& Smith, M. (1998). Crop evapotranspiration: Guidelines for computing crop water requirements. Irrigation and Drainage Paper 56. Rome: FAO.

Alvares, C. A., Stape, J. L., Sentelhas, P. C., Gonçalves, J. L. M., \& Sparovek, G. (2013). Koppen’s climate classification map for Brazil. Meteorologische Zeitschrift, 22(6), 711-728. https://doi.org/10.1127/ 0941-2948/2013/0507

Arnon, D. I. (1949). Copper enzymes in isolated chloroplasts. Polyphenoloxidase in Beta Vulgaris. Plant Physiology, 24(1). https://doi.org/10.1104/pp.24.1.1

Aujla, M. S., Thind, H. S., \& Buttar, G. S. (2007). Fruit yield and water use efficiency of eggplant (Solanum melnogena L.) as influenced by different quantities of nitrogen and water applied through drip and furrow irrigation. Scientia Horticulturae, 112, 142-148. https://doi.org/10.1016/j.scienta.2006.12.020

Bilibio, C., Carvalho, J. A., Martins, M., Rezende, F. C., Freitas, W. A., \& Gomes, L. A. A. (2010a). Função de produção da berinjela irrigada em ambiente protegido. Irriga, 15(1), 10-22. https://doi.org/10.15809/ irriga.2010v15n $1 \mathrm{p} 10$

Bilibio, C., Carvalho, J. A., Martins, M., Rezende, F. C., Freitas, E. A., \& Gomes, L. A. A. (2010b). Desenvolvimento vegetative e produtivo da berinjela submetida a diferentes tensões de água no solo. 
Revista Brasileira de Engenharia Agrícola e Ambiental, 14(7), 730-735. https://doi.org/10.1590/S1415-43 662010000700007

Chartzoulakis, K., \& Drosos, N. (1995). Water use and yield of greenhouse grown eggplant under drip irrigation. Agricultural Water Management, 28, 113-120. https://doi.org/10.1016/0378-3774(95)01173-G

Díaz-Pérez, J. C., \& Eaton, T. E. (2015). Eggplant (Solanum melongena L.) Plant growth and fruit yield as affected by drip irrigation rate. Hortscience, 50(11), 1709-1714. https://doi.org/10.21273/HORTSCI. 50.11.1709

Embrapa (Empresa Brasileira de Pesquisa Agropecuária). (2018). Sistema brasileiro de classificação de solos (5th ed.). Brasília: Embrapa Solos.

Fattah, M. A., \& Aoda, M. I. (2008). The impacts of water magnetizing and limited irrigation on some growth and yield characteristics of corn. Iraq Journal of Soil Sciences, 8(1), 19-30.

Ferreira, D. F. (2014). Sisvar: A guide for its bootstrap procedures in multiple comparisons. Revista Ciência e Agrotecnologia, 38(2). https://doi.org/10.1590/S1413-70542014000200001

Filgueira, R. A. R. (2003). Solanáceas: Agrotecnologia moderna na produção de tomate, batata, pimentão, pimenta, berinjela e jiló. Lavras: UFLA.

Gaveh, E. A., Timpo, G. M., Agodzo, S. K., \& Shin, D. H. (2011). Effect of irrigation, transplant age and season on growth, yield and irrigation water use efficiency of the African eggplant. Journal Horticulture, Environment, and Biotechnology, 52(1), 13-28. https://doi.org/10.1007/s13580-011-0054-3

Hozayn, M., Abdallha, M. M., Abd El-Monem, A. A., El-Saady, A. A., \& Darwish, M. A. (2011). Applications of magnetic technology in agriculture: A novel tool for improving crop productivity (1): Canola. African Journal of Agricultural Research, 11(5), 441-449. https://doi.org/10.5897/AJAR2015.9382

Jamaludin, D., Aziz, S. A., Ahmad, D., \& Jaafar, H. Z. E. (2015). Impedance analysis of Labisia pumila plant water status. Information Processing in Agriculture, 2, 161-168. https://doi.org/10.1016/j.inpa.2015.07.004

Karam, F., Saliba, R., Skaf, S., Breidy, J., Rouphael, Y., \& Balendonck, J. (2011). Yield and water use of eggplants (Solanum melongena L.) under full and déficit irrigation regimes. Agricultural Water Management, 98, 1307-1316. https://doi.org/10.1016/j.agwat.2011.03.012

Keller, J., \& Bliesner, R. D. (1990). Sprinkle and trickle irrigation. New York, Van Nostrand Reinhold.

Kirnak, H., Tas, I., Kaya, C., \& Higgs, D. (2002). Effects of déficit irrigation on growth, yield, and fruit quality of eggplant under semi-arid conditions. Australian Journal of Agricultural Research, 53, 1367-1373. https://doi.org/10.1071/AR02014

Levidow, L., Zaccaria, D., Maia, R., Vivas, E., \& Todorovic, M. (2014). Improving water-efficient irrigation: Prospects and difficulties of innovative practices. Agricultural Water Management, 146, 84-94. https://doi.org/10.1016/j.agwat.2014.07.012

Lichtenthaler, H. K. (1987). Chlorophylls and Carotenoids: Pigments of Photosynthetic Biomembranes, Methods in enzymology. Plant Cell Membranes, 148, 350-382. https://doi.org/10.1016/0076-6879(87)48036-1

Luengo, R. F. A., Calbo, A. G., Lana, M. M., Moretti, C. L., \& Henz, G. P. (1999). Classificação de Hortaliças. Brasília, Embrapa Hortaliças.

Mahmood, S., \& Usman, M. (2014). Consequences of magnetized water application on maize seed emergence in sand culture. Journal of Agricultural Science and Technology, 16, 47-55. https://doi.org/10.2166/ wrd.2016.216

Marouelli, W. A., Silva, W. L. C., \& Silva, H. R. (2001). Irrigação por aspersão em hortaliças: Qualidade da água, aspectos do Sistema e método prático de manejo. Brasília: Embrapa Informação Tecnológica: Embrapa Hortaliças.

Mohammadian, M., Fatahi, R. A., \& Emamzadei, M. R. N. (2015). Investigation the effect of magnetic salt water on yield and yield componentes of green pepper. Irrigation Sciences and Engineering, 39, 121-130.

Noran, R., Shani, U., \& Lin, I. (1996). The effect of irrigation with magnetically treated water on the translocation of minerals in the soil. Magnetic and Electrical Separation, 7(2), 109-122. https://doi.org/ $10.1155 / 1996 / 46596$ 
Prados, N. C. (1986). Contribución al estudio de los cultivos enarenados en Almeria: necesidades hídricas y extracción del nutrientes del cultivo de tomate de crescimento indeterminado en brigo de polietileno. Almeria: Caja Rural Provincial, Tesis Doctoral.

Rawabdeh, H., Shiyab, S., \& Shibli, R. (2014). The effect of irrigation by magnetically water on chlorophyll and macroelements uptake of pepper (Capsicum annuum L.). Jordan Journal of Agricultural Sciences, 10(2), 205-214.

Ribeiro, A. C., Guimarães, P. T. G., \& Alvarez, V, V. H. (1999). Recomendações para o uso de corretivos e

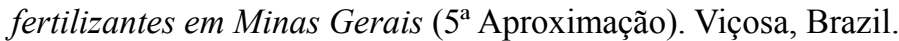

Souza, A. H. C., Rezende, R., Lorenzoni, M. Z., Seron, C. C., Hachmann, T. L., \& Lozano, C. S. (2017). Response of eggplant crop fertigated with doses of nitrogen and potassium. Revista Brasileira de Engenharia Agrícola e Ambiental, 21(1), 21-26. https://doi.org/10.1590/1807-1929/agriambi.v21n1p21-26

Surendran, U., Sandeep, O., \& Joseph, E. J. (2016). The impacts of magnetic treatment of irrigation water on plant, water and soil characteristics. Agricultural Water Management, 178, 21-29. https://doi.org/10.1016/ j.agwat.2016.08.016

Trani, P. E. (2014). Calagem e adubação para hortaliças sob cultivo protegido (1st ed.). Campinas: Instituto Agronômico.

Trani, P. E., Tivelli, S. W., \& Carrijo, O. A. (2011). Fertirrigação em hortaliças (2nd ed.). Série Tecnologia APTA. Boletim Técnico IAC, 196. Campinas: Instituto Agronômico.

\section{Copyrights}

Copyright for this article is retained by the author(s), with first publication rights granted to the journal.

This is an open-access article distributed under the terms and conditions of the Creative Commons Attribution license (http://creativecommons.org/licenses/by/4.0/). 